\title{
User Trusts: Broad-Based Ownership for Online Platforms
}

\author{
Nathan Schneider \\ University of Colorado Boulder \\ PREPRINT \\ Informatik Spektrum (2020) \\ https://doi.org/10.1007/s00287-020-01242-x
}

This essay introduces what promise a novel broad-based capital strategy - trusts serving platform users - might hold for the online economy, especially as an enabler of more widespread, organized, and democratic user accountability. It draws on lessons from the experience of employee ownership alongside emerging opportunities for other kinds of broad-based ownership structures. User-oriented trusts could enable meaningful co-governance and profit sharing among essential stakeholders, a prospect that merits research and experimentation.

The author is grateful for substantive input from Paul Bindel, Joseph Blasi, Greg Brodsky, David Ellerman, Camille Kerr, Morshed Mannan, Christopher Michael, Derek Razo, Danny Spitzberg, and Jason Wiener, in addition to financial support through a Louis O. Kelso Fellowship from the Rutgers School of Management and Labor Relations.

\section{Crisis and craving}

The companies formerly known as the "sharing economy" - a term mostly abandoned for want of actual sharing - have begun sharing ownership. As early as 2017, executives at the ride-sharing platform Uber reportedly met with US Securities and Exchange Commission officials about granting company stock to their independent-contractor drivers [1]. (Current policy enables stock distributions mainly to formal employees.) Airbnb, the homerental giant, filed a formal request to that effect with the SEC the following 
September [2], and Uber did the same just weeks later [3]. By February 2019, the Wall Street Journal reported that, with their initial public offerings approaching, Uber and its competitor Lyft found a way to work around SEC rules by issuing their drivers cash bonuses that recipients could choose to invest in stock $[4,5]$.

I confess to having felt a sense of vindication from these developments. In May 2017, I helped bring a grassroots shareholder proposal to Twitter's annual meeting, which invited the then-embattled company to study possibilities for user ownership [6-8]. At the time, the company tried to persuade the SEC to bar the proposal outright [9] and, upon being overruled, advised shareholders to vote against it [10]. But less than two years later, suddenly, some of Silicon Valley's biggest companies were trying to convince the SEC to let them turn users into owners.

The direction in which Airbnb, Lyft, and Uber have been gesturing could amount to much more than a scheme for boosting their initial public offerings, especially if they end up competing to offer ever-better deals. An accountability crisis has been ricocheting across the online economy in recent years; platform CEOs have been summoned to Washington for Congressional hearings and reprimands, while politicians threaten leading companies with antitrust action, regulation, and even nationalization. Prominent scholars have documented causes for concern about surveillance [11, 12], unjust discrimination $[13,14]$, monopolistic practices $[15,16]$, and labor abuses $[17,18]$. The proposed remedies generally involve either demanding better behavior within existing company structures, or government regulation along the lines of Europe's General Data Protection Regulation. Comparatively few proposals have sought to change to whom these companies are structurally accountable and who shares in their profits.

The Twitter shareholder campaign emerged out of a phenomenon known as "platform cooperativism," which calls for transforming the online economy through the cooperative business tradition [17, 19, 20]. Platform cooperativism has generated enthusiasm but encounters considerable challenges, as cooperatives are incompatible with much of the existing financial and legal infrastructure in tech hubs like Silicon Valley [21]. But I will suggest here that, alongside cooperativism, those seeking to shift the accountability of the online economy should draw from the legacy of broad-based capital ownership through employee stock-ownership plans, which during the last quarter of the twentieth century were responsible for a rapid expansion of rank-and-file employee ownership in the United States [22]. While cooperatives seek to 
bypass the capitalist corporate structure altogether, broad-based ownership schemes devise means of enabling widespread, equitable participation within the capitalist corporate paradigm.

Evidently, the online economy needs better options to take it through this well-earned accountability crisis. With the promise of government regulation comes the danger of compliance burdens that could crowd out newcomers, especially as multiple jurisdictions simultaneously attempt to regulate the intrinsically transnational Internet. User ownership could be a means, alongside appropriate regulation, of ensuring democratic self-governance and equitable profit-sharing from within companies themselves. But techniques for achieving this are lacking. The platform companies that sought SEC approval for even modest distributions of equity to their contractors had to devise workarounds short of their goals. Earlier-stage tech startups, meanwhile, have been calling for means of accessing capital that don't demand exponential returns for outside investors [23]. Both the biggest platforms and the newest startups are looking for more creative answers to the question of ownership.

This essay introduces what promise one such broad-based capital strategytrusts serving platform users - might hold for the online economy, especially as an enabler of more widespread, organized, and democratic user accountability. It draws on lessons from the experience of employee ownership alongside emerging opportunities for other kinds of broad-based ownership structures. User-oriented trusts could enable meaningful co-governance and profit sharing among essential stakeholders, a prospect that merits research and experimentation. The time may be coming for a renaissance of ownership designs [24] to help address the crises of accountability in the online economy, which otherwise have no end in sight. Like the proposal for Twitter shareholders, this is a call for further study toward that renaissance.

\section{"Extending the ESOP revolution"}

Lawyer, investment banker, and polemicist Louis O. Kelso began honing his lifelong economic theory while serving as a Navy intelligence officer in Panama during World War II [25]. Non-human capital, he concluded, contributes to production alongside labor, and thus full citizenship in the economy should involve not just employment but capital ownership as well. As capital increases its share in the productive matrix through technology, he reasoned, ownership can begin to eclipse people's dependence on employment altogether [26-28]. Kelso and his collaborators-notably, popular philosopher Mortimer 
Adler and political scientist Patricia Hetter Kelso - used various terms for this proposition and what it entails, such as two-factor theory, universal capitalism, democratic capitalism, and binary economics. But regardless of its name, with his idea came an agenda for dramatically expanding participation in capital ownership.

"The practical implication of Kelso's insights," Patricia Kelso explained after her husband's death, "is that we cannot efficiently produce goods and services through two factors while distributing income through just one" [29].

Kelso proposed a series of means by which the income generated through capital ownership could become more widely available. The proposals generally involved trust entities that could manage capital on behalf of beneficiaries and acquire new capital, such as company stock, with financing based on the expectation of future productivity. It was a kind of populist leveraged buyout, before the technique became popular among corporate raiders. The most successful version of this gambit, and the only one Kelso was able to significantly advance before his death in 1991, was the employee stockownership plan, or ESOP. Kelso first demonstrated the model in 1956, and after he secured its enshrinement in US employee-benefits law in 1974, the number of companies with an ESOP rapidly grew into the thousands. As a retirement plan, employee-owned stock is paid for by the employer, not out of the employee's pocket. Boards, bankers, retiring owners, and employees alike found reasons to embrace the model, particularly in certain types of firms best poised to benefit from the mix of costs and incentives. The National Employee Ownership Center now counts more than 14 million ESOP participants, through around seven thousand companies, in the United States [30].

Kelso's achievement suggests how, with a relatively small policy accommodation, a market can emerge and spread for a potentially transformative practice within capitalist companies. ESOPs were able to proliferate much faster and grow much larger, for instance, than worker cooperatives, which today in the United States number just several hundred, with several thousand employees among them [31]. The ESOP's trust structure enables its parent company to obtain financing on its behalf, while consolidating oversight and most governance powers in a single trustee [32]. The company's ability to make tax-deductible contributions to an ESOP, and the ability to defer taxes on the stock sold to it, helps make it cost-competitive even for directors who do not value employee ownership for its own sake. ESOPs have been used for such purposes as ownership succession, increasing employee engagement, 
self-financing firm growth, private equity turnarounds, and bolstering share value. ESOPs can operate within several kinds of existing capitalist company forms, both closely held and publicly traded.

The ESOP formula, however, comes with a set of shortcomings, which have contributed to the leveling-off of ESOP growth since the 1990s [33]. The balance of costs and benefits has contained ESOPs to particular kinds of corporate contexts (such as medium-sized, consistently profitable engineering firms) and kept them out of others (such as venture-backed tech startups, where stock-option plans are more common) [32]. And although ESOP law includes provisions designed to protect employees' interests, the employermanaged nature of the model has introduced opportunities for abuse [33]. Even those protections tend to privilege maximizing financial returns over other values that employees might hold, including the continued existence of the ESOP itself.

The fact that the ESOP came into law through the Employee Retirement Income Security Act of 1974 introduced certain limitations. It consigns the model to service primarily as a means for retirement savings, with features that make it cumbersome and unattractive in many contexts. Perhaps most significantly for the context of the online economy, it presumes the relevant stakeholder class to be formal employees. That is, it cannot be applied to the Airbnb, Lyft, and Uber user-contractors, much less the unpaid, value-creating users of a platform like Twitter. Uber, for instance, claims to contract with 3 million drivers, compared to only 16,000 formal employees [34].

The ESOP was never meant to be the only sort of broad-based ownership on hand. Louis and Patricia Kelso [27] referred to his most famous invention as "the Trojan Horse for democratizing American capitalism"-a starting point, not the destination. In their final book, on "extending the ESOP revolution," they proposed eight distinct kinds of capital ownership plans. Given the degree to which the ever more pervasive online economy relies on non-employee drivers, hosts, content moderators, custodians, warehouse staff, and content creators [35] - along with the rise of contingent work across the economy at large [36] - it may be time to move beyond the Trojan Horse, beyond the ESOP.

\section{User trusts}

Louis Kelso's second best-developed proposal - the consumer stock ownership plan, or CSOP — would be a plausible next step. Kelso and Kelso refer to it as 
"the capitalist equivalent of the socialist-derived producer cooperative" [27], with features of a consumer cooperative as well. He developed his primary CSOP experiment starting in 1957, with a farmer-owned fertilizer provider in California called Valley Nitrogen. The primary usefulness of CSOPs would be in cases of natural monopolies, such as power companies, or long-term consumer relationships, like grocery stores [27, 37]. They could operate in tandem with an ESOP for the company's workers. The Valley Nitrogen experiment ran aground due to changes in tax law, but with proper enabling legislation, Kelso envisioned that it could function, and access financing, much like an ESOP. Jens Lowitzsch, who holds the Kelso Professorship at Viadrina European University, has proposed CSOPs for municipal water systems [38] and renewable energy [39].

Although the conflation of consumer and producer stakeholders might seem to muddy the model, it proves prescient for the online economy. Multi-sided online platforms frequently blur the roles of consumer and producer in the ambiguous designation of the user - who might be an app-based delivery worker, an amateur video creator on a social-media platform, a resident of an area with only one broadband provider, or a smartwatch wearer whose biometric data is collected in a profitable database. The CSOP logic could have transformative relevance for each of these. The delivery worker could accumulate a long-term capital stake alongside irregular gigs; the video creator might weigh in on decisions that affect the craft; the monopolybroadband customer might have a way of demanding fair terms of service; the smartwatch wearer could have additional assurance, as a co-owner, that the company won't be misusing personal data. User trusts of these sorts would take into account that our economic lives do not begin and end in fixed employment relations. Such trusts could become the sole owner of a company, a majority shareholder, or the holder just a small minority of shares.

When we consider a broad-based ownership trust separate from the confines of employment law, we lose the current tax advantages of the ESOP, but we gain considerable opportunities - opportunities that may be deserving of their own legal recognition and incentives to encourage their use. For instance, a trust that isn't primarily a retirement plan allows more leeway for participants to intentionally craft its mission. Developments in trust legislation since Kelso's heyday enable perpetual purpose trusts that serve a stated purpose beyond value maximization for a set of beneficiaries [40, 41]. Some user trusts, such as for gig workers or broadband customers, could emphasize economic returns for participants through stock ownership. For 
startups, these might resemble stock options as a means of incentivizing early adoption. But for trusts whose participants may be making smaller or hard-to-calculate economic contributions to the business, such as the social-media personalities or smartwatch users, the trust could primarily be an advocate for user voice and values in corporate governance, devoting stock proceeds to fund such advocacy rather than distributing them among participants. Trusts oriented toward governance might be issued special classes of shares that have only voting rights, with or without financial rights.

Although Kelso imagined future dividends as the main financing mechanism for his plans, ESOPs have typically depended on tax-advantaged employeebenefit contributions [42]; especially since tech companies have tended to direct resources to growth rather than dividends, other means of funding a user trust are likely necessary. This could occur as a form of equity compensation or through a modified stock buyback. Like stock options in a startup, the trust might be oriented toward a future liquidity event, enabling users to benefit alongside founders and early investors. In some cases, again like stock options, there may be an expectation that users participate in the purchase financially themselves.

One way or another, a user trust should hold a stake sufficient to make a difference in the lives of its participants. It should also matter in a way distinct from simply owning shares in a public company. One of Twitter's arguments against our shareholder proposal was that users could (and already do) buy shares in the company [10]. We wanted something else, however - a relationship tied to our actual use of the platform, a kind of ownership not merely of individuals but of a collective able to wield collective influence. As a tool for delivering economic returns, a user trust could purchase shares on behalf of the vast majority of users who never would or could invest in the company with their own resources. As a mechanism of governance, such a trust could enable otherwise-atomized users and shareholders to speak with one voice on issues of common concern.

ESOPs have the capacity for involving employee participation in corporate governance, especially for decisions about liquidating the trust. But to allay management's fears of meddling underlings, and to keep focus on the task of running a retirement program, active employee governance (such as in regularly electing board members) has been relatively rare. Such a conservative approach may serve some user trusts well. Already, Google's parent Alphabet proposes to use a "data trust" vehicle for stewarding data gathered by its "smart city" urban sensors, with the intent of distancing 
control from both the company and the population subject to its surveillance $[43,44]$. The founder of the Chinese electric vehicle company NIO has put 50 million shares into a user trust that can deliver economic returns but no governance powers [45]. But in other cases, companies and employees have come to see active participation in governance as something to be encouraged; research on ESOPs, for instance, suggests that combining ownership and inclusive governance can have positive effects on productivity [22], and ESOP companies have sought to reap those benefits through practices like open-book management. Platform companies might similarly see value in cultivating highly participatory user trusts. Large user communities could draw on methods such as quadratic voting [46], sortition [47], and liquid democracy [48] to enable efficient, inclusive participation.

Consider Facebook, for instance. As a company now habitually embattled in accountability crises, it could be a valuable sign of goodwill to adopt a user governance regime with power at the level of a large bloc of shares and even board representation. CEO Mark Zuckerberg himself has written about the need for forms of user governance on the platform [49]. He has also committed to relinquishing nearly his entire stake in the company to fund charitable endeavors. Perhaps a leveraged user trust would be a convenient vehicle for addressing the challenges of accountability, governance, and divestment all at once.

User trusts of various kinds could become a new norm in the online economyfor startups seeking to draw early adopters and buy out their investors, or for larger platforms maturing into roles as near-monopoly utilities. Companies would then have to compete with each other to offer more and more attractive, responsible trust arrangements to win the loyalty of potential users. A market could emerge for private-equity firms and others to finance CSOP formation. As with the ESOP, all this could take place within conventional capitalist companies, in tandem with existing financial infrastructure. Through both shared wealth and shared governance, online platforms could operate less like the investor fiefdoms that are so common today and more like laboratories of democracy.

\section{Further action-research}

Louis Kelso's crusade to bring capital ownership to more people's economic lives may be even more relevant today than in his time. The divide between those who do and don't own capital is an important driver of widening wealth inequality [50]. Forms of accessible co-ownership could be an antidote 
to chronic wage stagnation and anxieties about job-replacing automation. Strategies beyond the ESOP, like the CSOP and other "SOPs" [37], don't assume that fixed employment is our sole form of economic life, or the sole form relevant to ownership. At a time when the former expectation (at least among privileged classes) of a lifelong salary with benefits has frayed, Kelsoism presents a schematic for new mechanisms of widespread economic security, even economic democracy. This legacy bears relevance for models gaining momentum today such as social wealth funds, universal basic income, platform cooperativism, and benefit corporations. But there is much still to be learned about whether and how Kelso's sketches might someday come to life on the platforms that orchestrate the twenty-first-century economy.

The idea of user trusts for online platforms remains speculative, in need of substantial further investigation and experimentation. For instance, some areas of further inquiry should include:

- Applicable trust structures and other vehicles (such as stock-holding cooperatives [51, 52] and blockchain networks [53]), across various jurisdictions and legal contexts

- Policy interventions to encourage the development of a market for user trusts, attractive to both platform companies and their users

- Additional policies that might obligate certain kinds of utility-scale companies to include user trusts (similar to laws requiring worker co-determination for corporations over a certain size)

- Limits and opportunities for serving the multinational user bases of transnational platforms

- Necessary protections, including legal constraints and rights to organize, that shield user-trust participants from deception, manipulation, and abuse

- Business models for financing CSOP formation, such as through privateequity and other investment firms

- Relevant guardrails for startups seeking to retain user ownership as an exit option for early investors and founders

One thing the ESOP legacy suggests is that research alone will not be nearly as instructive as conducting such investigations in the field of practice, the way Louis Kelso and his associates did. Trying out new experiments with company equity might seem like a lot to ask, except that even companies with much to lose like Airbnb, Lyft, and Uber already seem willing to attempt programs that do so. Regulators, meanwhile, are grasping for better ideas about how to bring online platforms to account. Users deserve better options, 
too.

According to Patricia Kelso, Louis Kelso frequently observed a pattern among those around him: "People refuse to recognize a problem, he said, until they see its solution" [29]. Opinion research has found widespread feelings of powerlessness and resignation with how online platforms gather, monetize, and manipulate personal data [54]. Users have little choice but to accept platforms' terms of use as given. User trusts, or any other structural contrivance, cannot pretend to be the solution to the bewildering array of problems that the online economy presently poses. Democracy is never a drop-in fix for anything or everything. It is, rather, a manner of taking responsibility, and of wielding the power that responsibility requires. Having a tool of this sort on hand might allow more people to finally regard the online economy's problems with agency rather than resignation, because now they can be part of finding solutions.

\section{References}

1. Primack D (2017) Uber has met with SEC about giving drivers equity. In: Axios. https://www.axios.com/uber-has-met-with-sec-about-giving-driversequity-1513303337-3659f2e1-a795-43c5-8ddd-ea7ae372fc94.html. Accessed 14 März 2019

2. Chesnut R Re: Request for Comment on Concept Release on Compensatory Securities Offerings and Sales

3. Burr D (2018) Re: Concept Release on Compensatory Securities Offerings and Sales

4. Robbins RB, Schlaefer CV, Lutrin J (2018) From Home Sharing and Ride Sharing to Shareholding. In: Pillsbury Law. https://www.pillsburylaw.com/ en/news-and-insights/rule-701-revision-uber-airbnb.html. Accessed 3 Juli 2019

5. Farrell M Some Uber, Lyft Drivers to Get Stock in IPOs. Wall Street Journal: Markets

6. \#BuyTwitter (2017) Democratize the People's News Network. https: //www.buytwitter.org/. Accessed 15 März 2019

7. Spitzberg D (2017) \#GoCoop: How the \#BuyTwitter Campaign Could Signal a New Co-op Economy. The Cooperative Business Journal 12-19 
8. Lang M (2017) \#BuyTwitter Shareholder Push Fails, but Supporters Hold out Hope. San Francisco Chronicle

9. McNair MS (2017) Twitter, Inc. Incoming Letter Dated January 20, 2017 10. Twitter (2017) Proxy Statement: Notice of 2017 Annual Meeting of Stockholders

11. Pasquale F (2015) The Black Box Society. Harvard University Press, Cambridge, MA

12. Zuboff S (2019) The Age of Surveillance Capitalism: The Fight for a Human Future at the New Frontier of Power. PublicAffairs, New York

13. Noble SU (2018) Algorithms of Oppression: How Search Engines Reinforce Racism. NYU Press, New York

14. Eubanks V (2018) Automating Inequality: How High-Tech Tools Profile, Police, and Punish the Poor. St. Martin's Press

15. Khan LM (2017) Amazon's Antitrust Paradox. Yale Law Review 126:564907

16. Wu T (2018) The Curse of Bigness: Antitrust in the New Gilded Age. Columbia Global Reports

17. Scholz T (2017) Uberworked and Underpaid: How Workers Are Disrupting the Digital Economy. John Wiley \& Sons, New York

18. Schor JB (2017) Does the sharing economy increase inequality within the eighty percent?: Findings from a qualitative study of platform providers. Cambridge J Regions Econ Soc 10:263-279. https://doi.org/10.1093/cjres/ rsw047

19. Scholz T, Schneider N (2016) Ours to Hack and to Own: The Rise of Platform Cooperativism, a New Vision for the Future of Work and a Fairer Internet. OR Books, New York

20. Schneider N (2018) An Internet of Ownership: Democratic Design for the Online Economy. The Sociological Review 66:

21. Schneider N (2018) Everything for Everyone: The Radical Tradition That Is Shaping the Next Economy. Nation Books, New York

22. Blasi J, Kruse D, Freeman RB (2018) Broad-based employee stock ownership and profit sharing: History, evidence, and policy implications. 
Journal of Participation and Employee Ownership 1:38-60. https://doi.org/ 10.1108/JPEO-02-2018-0001

23. Griffith E (2019) More Start-Ups Have an Unfamiliar Message for Venture Capitalists: Get Lost. The New York Times

24. Kelly M (2012) Owning Our Future: The Emerging Ownership Revolution. Berrett-Koehler Publishers, San Francisco

25. Speiser SM (1977) A Piece of the Action: A Plan to Provide Every Family with a $\$ 100,000$ Stake in the Economy. Van Nostrand Reinhold Co., New York

26. Kelso LO, Kelso PH (1967) Two-factor Theory: The Economics of Reality. Vintage Books, New York

27. Kelso LO, Kelso PH (1986) Democracy and Economic Power: Extending the ESOP Revolution through Binary Economics. Ballinger Publishing, Cambridge, MA

28. Ashford R (1996) Louis Kelso's Binary Economy. The Journal of SocioEconomics 25:1-53. https://doi.org/10.1016/S1053-5357(96)90052-9

29. Kelso PH (2005) What Louis Kelso Knew. In: The Kelso Institute. http: //kelsoinstitute.org/louiskelso/kelso-paradigm/what-louis-kelso-knew/. Accessed 19 März 2019

30. National Center for Employee Ownership ESOPs by the Numbers. https://www.nceo.org/articles/esops-by-the-numbers. Accessed 16 März 2019

31. Democracy at Work Institute Worker Cooperative FAQ. https://institute. coop/worker-cooperative-faq. Accessed 17 März 2019

32. Rosen C, Rodrick S (2018) Understanding ESOPs. National Center for Employee Ownership, Oakland, CA

33. Kroncke JJ (2018) ESOPs and the Limits of Fractionalized Ownership. University of Chicago Legal Forum 2017:40

34. Uber (2019) Company Information. In: Uber Newsroom. https://www. uber.com/newsroom/company-info/. Accessed 20 März 2019

35. Cherry MA (2015-2016) Beyond Misclassification: The Digital Transformation of Work. Comp Lab L \& Pol'y J 37:577-602 
36. Katz LF, Krueger AB (2016) The Rise and Nature of Alternative Work Arrangements in the United States, 1995-2015. National Bureau of Economic Research, Cambridge, MA

37. Hockett R (2007) What Kinds of Stock Ownership Plans Should There Be - Of ESOPs, Other SOPs, and Ownership Societies. Cornell Law Review $92: 865$

38. Lowitzsch J (2016) Community participation and sustainable investment in city projects: The Berlin Water Consumer Stock Ownership Plan. Journal of Urban Regeneration and Renewal 10:14

39. Lowitzsch J (2018) Energy transition: Financing consumer co-ownership in renewables. Springer Berlin Heidelberg, New York, NY

40. Michael C (2017) The Employee Ownership Trust, an ESOP Alternative. Probate \& Property 31:42-47

41. Purpose Foundation (2019) Steward-Ownership: Rethinking Ownership in the 21st Century

42. Ellerman D (2015) Comments on Robert Hockett's Papers

43. Dawson AH (2018) An Update on Data Governance for Sidewalk Toronto. In: Sidewalk Labs. https://www.sidewalklabs.com/blog/an-update-on-datagovernance-for-sidewalk-toronto/. Accessed 28 Juni 2019

44. McDonald S (2019) Reclaiming Data Trusts. In: Centre for International Governance Innovation. https://www.cigionline.org/articles/reclaimingdata-trusts. Accessed 28 Juni 2019

45. Fan Z (2019) William LI Transfers His 50 Million Ordinary Shares to NIO User Trust As Promised. In: EqualOcean. https://equalocean.com/auto/ 20190124-nios-one-more-step-to-become-the-users-enterprise. Accessed 13 Okt 2019

46. Posner EA, Weyl EG (2014) Quadratic Voting as Efficient Corporate Governance. The University of Chicago Law Review 81:251-272

47. Bouricius T (2013) Democracy Through Multi-Body Sortition: Athenian Lessons for the Modern Day. Journal of Public Deliberation 9:

48. Hardt S, Lopes LCR (2015) Google Votes: A Liquid Democracy Experiment on a Corporate Social Network. Technical Disclosure Commons 
49. Zuckerberg M (2017) Building Global Community. In: Facebook. https://www.facebook.com/notes/mark-zuckerberg/building-globalcommunity/10154544292806634. Accessed 18 März 2019

50. Alvaredo F, Atkinson AB, Piketty T, Saez E (2013) The Top 1 Percent in International and Historical Perspective. Journal of Economic Perspectives 27:3-20. https://doi.org/10.1257/jep.27.3.3

51. Bhowmik SK (1994) Workers as Shareholders: Case for Closer Examination. Economic and Political Weekly 29:2580-2582

52. Ellerman D (2019) A Generic Model for Employee Stock Ownership Plans. Institute for Economic Democracy, Ljubljana, Slovenia

53. Rudolf M Tokenizing Startup Equity, Part 1 - Employee Stock Options Plan (ESOP) on Ethereum Blockchain. In: Neufund. https://blog.neufund.org/tokenizing-startup-equity-part-1-employeeincentive-options-plan-esop-on-ethereum-blockchain-dce2416f4505. Accessed 19 März 2019

54. Turow J, Hennessey M, Draper N (2015) The Tradeoff Falacy: How Marketers Are Misrepresenting American Consumers and Opening Them Up to Exploitation. Annenberg School of Communication, University of Pennsylvania 